This is obviously very different from Canada's MRC whose 40 study sections of 10 to 15 members each meet twice a year for 2-3 days to review some 50 applications each, or NIH's 100 study sections of 10-20 members each that meet three times a year to deal with 50 to 70 applications each time. I wonder what percentage of the grant budget is spent on these review processes in Canada and the United States?

The Japanese granting agencies undoubtedly spend far fewer resources on the evaluation process. No comments or suggestions are sent back to the applicants, so there is no way for them to know why their application has been successful or unsuccessful.

For most of the applicants, the review process is almost like a lottery, winning and losing without any reason other than luck. This is also quite different from the North American system where the applicants receive extensive comments from the study section.

Monopoly (or oligopoly) of the distribution of grants among the institutions discussed in the News article is not a unique problem of this new category of grant. Among the 68 large group grants for research in natural science selected as "priority research areas" (juten kenkyuhi) by Monbusho for 1996 and 1997, 37 and 32 per cent respectively of their 'leaders' are affiliated with the University of Tokyo, 12 and 15 per cent respectively are from Kyoto University, while Osaka University, Nagoya University and Tohoku University account for 10 per cent each. Thus only 25 per cent is distributed among the other 93 national universities (not to mention municipal, prefectural and private universities).

Fundamental reform is required in these two areas of difference. Otherwise, Japan's rapidly increasing budgets for science will merely result in more money being poured into the already rich universities. And the increased funds will be useless for improving the foundations of Japanese science. It is not enough just to complain about the unfairness of one particular type of big grant.

\section{Shinji Yokoyama}

Nagoya City University Medical School, Kawasumi 1, Mizuho-cho, Mizuho-ku,

Nagoya 467, Japan

e-mail: syokoyam@cmews2.med.nagoyacu.ac.jp

\section{Cultural credits}

SIR - In her review of my book, The Prehistory of Sex: Four Million Years of Human Sexual Culture (Nature 383, 683; 1996), Yvonne Marshall accuses me of poor referencing and of falsely claiming certain ideas as my own, such as my insis- tence on the critical importance of the invention of the baby-carrying sling in human biocultural evolution. In fact, in 32 pages of endnotes and more than 440 references, I fully credit the work of those whom she claims I ignore (pages 273, 275, 276) $)^{1-4}$

Marshall's frustration at not being able to pigeonhole me or my arguments may stem from the fact that they are not purely cultural as she implies, but biological too. Anyone with passing knowledge of primatology would know that the idea that penis size increased while clitoris size decreased in early hominid evolution is uncontentious $^{5,6}$, although the reasons for it are not ${ }^{7}$.

\section{Tim Taylor}

Department of Archaeological Sciences, University of Bradford,

West Yorkshire BD7 1DP, UK

e-mail: T.F.Taylor@bradford.ac.uk

1. Bolen, K. in Exploring Gender Through Archaeology: Selected Papers from the Boone Conference (ed. Classen, C.) 49-62 (Monographs in World Archaeology 11; Prehistory Press, Madison, 1992).

2. Tanner, N. \& Zihlman, A. Signs: Journal of Women in Culture and Society 1 (3), 585-608 (1976)

3. Zihlman, A. in Sex and Gender Hierarchies (ed. Miller, B. D.) 32-79 (Cambridge Univ. Press, 1993).

4. Zihlman, A. Nature 364, 585 (1994).

5. Smith, R. L. (ed.) in Sperm Competition and the Evolution of Animal Mating Systems, 618-659 (Academic, London, 1984).

6. Dixson, A. F. J. Zool. Soc. Lond. 213, 423-443 (1987)

7. Margulis, L. \& Sagan, D. Mystery Dance: On the Evolution of Human Sexuality (Simon \& Schuster, London, 1991).

Would you like to save one hour in histidine-tagged protein purification?

To load, purify and elute in 15 minutes? Now it's possible-time after time. 